averaged 22 days, it is likely that most VRE-colonized patients were identified through the surveillance system. Six control-patients were excluded, because their length of hospitalization was shorter than the median duration of hospitalization before VRE BSI of case-patients. The inclusion of these short-stay patients likely would have skewed results, as they would not have had the same opportunity to develop VRE BSI; most likely, these patients would have been even less severely ill and less likely to have mucositis than the controls who were included.

Degree of neutropenia was not found to be a significant risk factor on either univariate or multivariate analysis. Since the median absolute neutrophil count in both caseand control-patients was zero on the hospital day of study (emphasizing the profundity of immunosuppression in our population), this factor likely did not optimally reflect differences in immune system function.

Our study found that increased severity of mucositis is independently associated with VRE BSI in hospitalized cancer patients, most of whom were known to be VRE-colonized. The association of mucositis with VRE BSI may indicate diffuse gastrointestinal mucosal breakdown, which promotes bloodstream invasion by gut-colonizing VRE. Gastrointestinal complications may further increase the risk of VRE BSI. Recently, the presence of $C$ difficile has been identified as a risk factor for VRE BSI in patients with acute leukemia. ${ }^{12}$

Interventions to ameliorate the severity of mucositis or to alter VRE colonization status may help to prevent VRE BSI in VRE-colonized cancer patients. Antimicrobial therapy, such as mupirocin, has been shown to be ineffective in eradicating VRE carriage. ${ }^{13}$ Other interventions, such as alteration of gastrointestinal flora through addition of Lactobacillus, deserve investigation. ${ }^{14}$ Ultimately, prevention of VRE colonization is the most effective way to prevent VRE infection. Active surveillance and cohorting of high-risk patients, such as those with hematologic malig- nancy and mucositis, may be the most effective intervention to prevent VRE infection. ${ }^{15}$

\section{REFERENCES}

1. Murray BE. The life and times of the Enterococcus. Clin Microbiol Rev 1990;3:46-65.

2. Spera RV Jr, Farber BF. Multiply-resistant Enterococcus faecium: the nosocomial pathogen of the 1990s. JAMA 1992;268:2563-2564.

3. Centers for Disease Control and Prevention. Nosocomial enterococci resistant to vancomycin-United States, 1989-1993. MMWR 1993;42:597-599.

4. Edmond MB, Ober JF, Dawson JD, Weinbaum DL, Wenzel RP. Vancomycin-resistant enterococcal bacteremia: natural history and attributable mortality. Clin Infect Dis 1996;23:1234-1239.

5. Shay DK, Maloney SA, Montecalvo M, Banerjee S, Wormser GP, Arduino MJ, et al. Epidemiology and mortality risk of vancomycin-resistant enterococcal bloodstream infections. I Infect Dis 1995;172:993-1000.

6. Edmond MB, Ober JF, Weinbaum DF, Pfaller MA, Hwang T, Sanford MD, et al. Vancomycin-resistant Enterococcus faecium bacteremia: risk factors for infection. Clin Infect Dis 1995;20:1126-1133.

7. Montecalvo MA, Shay DK, Patel P, Tacsa L, Maloney SA, Jarvis WR, et al. Bloodstream infections with vancomycin-resistant enterococci. Arch Intern Med 1996;156:1458-1462.

8. Elting LS, Bodey GP, Keefe BH. Septicemia and shock syndrome due to viridans streptococci: a case-control study of predisposing factors. Clin Infect Dis 1992;15:33-48.

9. Bochud P, Calandra T, Francioli P. Bacteremia due to viridans streptococci in neutropenic patients: a review. Am J Med 1994;97:256-264.

10. Bochud PY, Eggiman P, Calandra T, Van Melle G, Saghafi L, Francioli P. Bacteremia due to viridans Streptococcus in neutropenic patients with cancer: clinical spectrum and risk factors. Clin Infect Dis 1994;18:25-31

11. Woo SB, Sonis ST, Monopoli MM, Sonis AL. A longitudinal study of oral ulcerative mucositis in bone marrow transplant recipients. Cancer 1993;72:1612-1617.

12. Roghmann MC, McCarter RJ, Brewrink J, Cross AS, Morris JG. Clostridium difficile infection is a risk factor for bacteremia due to VRE in VRE-colonized patients with acute leukemia. Clin Infect Dis 1997;25:1056-1059.

13. Montecalvo MA, Horowitz H, Wormser GP, Seiter K, Carbonaro CA. Effect of novobiocin-containing antimicrobial regimens on infection and colonization with vancomycin-resistant Enterococcus faecium. Antimicrob Agents Chemother 1995;39:794.

14. Elmer GW, Surawicz CM, McFarland LV. Biotherapeutic agents. A neglected modality for the treatment and prevention of selected intestinal and vaginal infections. JAMA 1996;275:870-876.

15. Jochimsen EM, Fish L, Manning $K$, et al. Evaluation and control of vancomycin-resistant enterococci at an Indianapolis hospital. Seventh Annual Meeting of the Society for Healthcare Epidemiology of America, St Louis, MO, April 27-29, 1997. Abstract.

\title{
HCV in HIV-Infected Hemophiliacs: An Opportunistic Infection
}

\section{Gina Pugliese, RN, MS Martin S. Favero, PhD}

Lesens and colleagues from the Montreal General Hospital, Montreal, Quebec, Canada, investigated the hypothesis that hepatitis $C$ virus (HCV) infection behaves like an opportunistic infection in which progressive liver disease (PLD) is the principal manifestation.

PLD in 81 hemophiliacs coinfected with HCV and HIV was compared with $53 \mathrm{HIV}$-seronegative $\mathrm{HCV}$-infected hemophiliacs. Progression to AIDS and death in $22 \mathrm{HCV}$ - and HIVcoinfected hemophiliacs with PLD was also compared with 59 coinfected hemophiliacs who did not develop PLD. The risk of PLD occurrence associated with an HIV-positive status was 7.4. In the coinfected group, the risk of PLD occurrence was higher in subjects with severe AIDS-defining immunodeficiency than in those without. Persons with PLD also had a faster progression to AIDS than those without PLD.
The researchers concluded that, as with other chronic resident human viruses, $\mathrm{HCV}$ should be considered another opportunistic pathogen in HIV disease.

FROM: Lesens O, Deschenes $M$, Steben M, Belanger G, Tsoukas CM. Hepatitis $C$ virus is related to progressive liver disease in human immunodeficiency virus-positive hemophiliacs and should be treated as an opportunistic infection. I Infect Dis 1999; 179:1254-1258. 